\title{
Environmental Utilization as Learning Resource by Geography Teacher to Apply Religius Characteristic in Public High School (SMAN) Lombok Timur
}

\author{
*Rezita Apriani ${ }^{1)}$ and Rahmanelli ${ }^{2)}$ \\ 1) Master Program Student of Geography Education Faculty of Social Science, Universitas Negeri Padang, \\ INDONESIA \\ 2) Department of Geography, Universitas Negeri Padang, INDONESIA
}

Email: rezitaapriani26@gmail.com

*Corresponding Author, Received: February 17, 2018, Revised: April 25, 2018, Accepted: May 01, 2018

This is an open acces article distributed under the Creative Commons 4.0 Attribution License, wich permits unregtricted use, Distribution, and reproduction in any medium provided the original work is properly cited @2017 by author and Universitas Negeri Padang

\begin{abstract}
This study is purposed to obtain objective data about environmental availability as a learning source and its relevance to Core Competency (KI) and Basic Competency (KD) of public senior high school (SMAN) in East Lombok; the use of environment as a learning source by geography teachers to shape religious characters and to know teacher barriers in using environment as a learning source, and also to determine priority of directive policy in utilizing environment as a learning source in geography subject at SMAN East Lombok. Type of research was qualitative research. Data were collected through observation, interview, and documentation. Data analysis consisted of data reduction, data presentation, verification, and ISM (Interpretative Structural Modeling). This study found out that: (1) in aspect of environmental availability as a learning source, physical and non physical environment are available to be used as a learning resource and it is relevant to KI and KD in SMAN East Lombok. (2) In utilization aspect, the form of physical and non physical utilization in religious characteristic application at school has been exploited by geography teacher to form religious character. However, environmental utilization outside the school is not optimal, because of the obstacles. (3) Constraints that teacher encounter are to coordinate students, infrastructure, to make plan, to understand parties that involved such as parent and family consent, to analyze the availability in the development of learning resources. (4) Policy priority that arise in utilizing the environment as a source of geography learning is improving skill development of geographic teacher implementation in collaboration with other offices and schools; structural planning by geography teachers to utilize the environment as a learning source and established a committee to explore the availability; analyzing condition and availability in the development of learning resources.
\end{abstract}

Keywords: Environment, Learning Resource, Religious Characteristic

\section{Introduction}

Human existence in the world is closely related to the environmental conditions where they live (Hermon, 2014). Human activities will not be separated from the interaction between individuals and between human and their environment. One of the sciences that examine human interaction with its environment is geography. Basically geography discusses the interaction of human and the surrounding environment, and symptoms in earth environment as a whole in aspect of interaction and spatial relationship. Geography is one of sciences that describes earth condition and analyze the phenomena of nature, so that geography will not be separated with environment. The environment is significance for living things. Environment is an area of natural habitat and it is affecting the development and behavior of human being. So that the environment can 
be used as a place of living things to interact, socialize, even can be used as a learning resource that is studied directly by observing changes and other symptoms in learning activities.

In the implementation of learning requires a variety of learning resources. The main goal of learning resources according to Sitepu (2014) is to help students to learn, understand, and master new skills and to motivate them to independently learn more. Learning resources have an important role in supporting learning process. An effective learning process is a learning process that uses a wide variety of learning resources. According to Ahmad Rohani (1997) teaching and learning activities will be more effective and efficient in achieving instructional goals if it is involving patterned learning resources, because learning source is important component and very useful. With the availability of various learning sources and its utilization in appropriate and contextual manner, it will be able to increase student knowledge with teacher directions.

Teacher is an educator who provide knowledge so that students can obtain knowledge that can be used for the future. Teacher has a very important role in teaching and educating students. Creative, innovative and competent teacher is important factors in promoting education, because the quality of students and education depend on the quality of teacher. One of teacher's basic skills is the ability to plan and implement teaching and learning process. So in the implementation of learning, teacher is not the only learning source, but teacher should be facilitating students to learn.

Teacher in the education unit has an obligation to plan learning process. As set forth in the Graduate Competency Standard and Content Standard Number 22 of 2016, one of learning principles is teacher as the only learning source that used various learning resources. Various learning resources will be meaningful to improve the quality of education. The role of teacher in choosing learning resources is very important in learning process. Teacher should utilize learning resource to make learning becomes fun and not boring, and easy to understand for students. Geography teacher can take advantage of the environment as a learning resource and are able to make the environment a good learning source that engaging and effective. It will support learning objectives to be achieved splendidly. Because it is in line with (Abdul Aziz, K 2015) that the learning resource center is the backbone of education and it is a pioneer in utilizing modern techniques used in education and all learning processes. So, learning source as the backbone of education in teaching and learning process should be fun, so that it will be ease to be accepted by students in instilling the value and development of character education.

Character education is the cultivation of essential values with learning and facilitation so that students as individual is able to understand, experience, and integrate the values that become core values into their personality (Sugandi, 2015). In accordance with the purpose of national education Chapter II article 3 UURI Number 20 of 2003 also explained that the National Education is aimed to develop student's potential to become human beings who believe and piety to God Almighty, to be noble, healthy, knowledgeable, capable, creative, independent, and become a democratic and responsible citizen. Therefore, character education should be developed in schools with the role of teachers is to chose learning resources in the learning process. Geography teachers can take advantage of the environment as a learning source and be able to make the environment a good learning source, interesting and effective to apply religious characteristic. It can support learning objectives to be achieved splendidly.

Based on observations, writer found out some problems in learning resources where students needed teachers direction in application of various learning resources. Large school yards and school location which is close to halal tourism area can be used as a learning resource to apply religious characteristics. This strategic location of school was able to give advantage where surrounding environment could be a learning source, so that writer was interested to examine more deeply about the use of environment as a learning source by geography teacher in applying religious characteristics in SMAN East Lombok.

\section{Method}

This study was qualitative research. Moleong (2012) suggested that "Qualitative Research was a study that intended to understand the phenomenon of what was experienced by research subjects such as behavior, perception, motivation, action and others, holistically and by way of description in the form of words and language, in a specific context which was natural and by utilization of various scientific methods ". Data were collected through observation, interviews, and documentation. Data analysis consisted of data reduction, data presentation, verification, and ISM (Interpretative Structural Modeling) to study about directive policy (Hermon, 2017). Interpretative Structural Modeling (ISM) is a methodology for understanding and designing 
structures with complex problems. According to Iswandi and Indang (2017), ISM is one of the computer-based methodologies that assisting in identifying the relationship between ideas and fixed structure on complex issues.

\section{Results and Discussion \\ Availability of Environment as Learning Source by Geography Teacher at SMAN East Lombok}

In this study, writer found out that various features of physical environment that surrounding schools was suitable to be utilized as learning resources such as forest, hill, vegetation, flora, fauna, wind, river, soil, sun , clouds, and wind. From non-physical aspects of the environment, learning resources were also available such as traditions, customs, social institutions, and community interactions. Both aspects were relevant to the Core Competency and Basic Competency of High School. In line with the AECT (Association for Educational Communication and Technology) in Vienna Sanjaya (2008), one of learning resources that can be used in the learning process is school environment and also environment outside the school that are deliberately designed or not specifically prepared for learning.

The availability of physical and non physical environments in East Lombok can be used as a learning resource by geography teacher where it is relevant to basic competency (KD). In accordance with KD relevancy to subject matter, the steps in utilizing the environment as a learning resource for applying religious characteristics can be done by preparation of learning plan by teacher in using learning resources, provision of subject matter, field trips or school practice.

\section{Environmental Utilization as a Learning Resource by Geography Teacher to form Religious Character in SMAN East Lombok}

From the availability of environment in East Lombok, teacher can use it in learning process. The Learning Implementation Plan (RPP) which made by the geography teacher was not fully created a complete RPP components and preparation of the RPP was not in accordance to the steps that established in existing provisions. Overall, geography teacher has been paying attention and compiling RPP in accordance with Regulation of Education Ministry (Permendikbud) number 22 of 2016. Writer did not find the utilization of environment as learning resource around the halal tourism area to form the religious character in learning process. In line with Ahmad Rohani (1997), teaching and learning activities will be more effective and efficient to achieve instructional goals if it involving learning resources in a planned manner, because the learning source is an important component and very useful. With the availability and appropriate and contextual utilization of various sources of learning, it will be able to increase student's knowledge with teacher's direction.

From interviews, geography teachers chose the criteria of learning resources and adjusted it to material and indicators to be achieved. Geography teachers always used learning resources in the learning process. Some learning resources that used were books, media, globe, maps, and public events about daily life application. If the subject matter was related to the physical environment such as the flora fauna, geography teacher used book and environment as learning resources. From students' ability to use learning resources, it was depended on each student's capability to understand the subject matter, and students had better understanding the material when environment as a learning resources were used where it was easily understood to study the real object.

From documentation analysis, interviews and observations as a whole, geography teacher, as well as schools, in Halal Tourism area of SMAN Lombok Timur that used the 2013 Curriculum in implementation of physical and non physical environment as a learning resource was cultivated the values in religious characters, but outside school environment was not utilized optimally as a learning resource in the development of religious character. In line with Abdul Majid (2012: 171) "Learning resources will be meaningful for students and teachers if the learning source is organized through a design that allows one to use it as a learning source. If not then the place or the natural environment, objects, people, and/or books are just places, objects, people or books that do not mean anything ".

Implementation of character values through the integration of school culture in the classroom includes the learning process of each subject or activity that designed appropriately (Kemendiknas: 2010). Class cultures that reflect the implementation of student's religious character such as to greet and shake hands with the 
teacher, march in front of classroom and greet the teacher, pray before and after the study, and every Friday perform IMTAQ activities, give infaq, read Quran and tahmid (Islamic lord's prayer). Based on the theory of Glok and Strak in Ancok and Suroso (2001), they divide religious dimension in five aspects that is religious belief, religious practice, religious felling, religious knowledge, and religious effect.

Islamic culture at school when student meets teacher is says salam (greeting) where it is a class culture that belongs to the five dimensions by practicing religion in daily life; in this activity also emerged a sense of mutual respect with people with older age. In the process of learning when utilizing the environment as a learning source, teachers have connected each subject matter to the formation of religious character which is environment is a gift from the God the Almighty. And teacher has given awareness of how important it is to be grateful and to be able to interact among human beings and the environment. However, teacher was not optimally utilizing the environment outside the school as a learning resource. Schools has been successfully implemented the value of character education in religious value because it has been achieving the indicator of school success in accordance with the Ministry of National Education regulation (2010), such as celebrating religious holidays, having facilities that can be used for worship, and teaching all students to pray before and after study \& meals, and teaching all students to study worship especially shalat (Islamic pray). The form of physical and non-physical utilization in applying religious characteristic available in the school environment has been exploited by geography teacher. However, utilization of environment outside the school has not been optimal because of the obstacles.

\section{Teacher's Limitation in Utilizing the Environment as a Learning Source in Geography Learning}

The use of physical and non physical environment as a learning resource is not optimal in the development of religious character based on interviews that conducted to some geography teachers about the perceived barriers in utilizing the environment as a learning source. It was obtained the conclusion that in the utilization of physical environment and non physical, constraints that teacher frequently found was to coordinate students, infrastructure, and plan to parties involved such as parent, and analysis of the availability in the development of learning resources. In accordance with writer's literature review, according to Sitepu (2014) to use learning resources outside the school requires teacher briefing on the aspects and focus on observation. So in utilizing the environment as a learning resource, teacher must play an important role in the implementation of the learning process because students need directions. In line with the references that writer uses, according to Usman (2011) "the more accurate teacher is performing function, the more secure, developed, and forming readiness and reliability in individual to become a developed person". In other words, the future portrait and faces of the nation will be reflected from self-portrait of today's teachers, and the advancement of the dynamics in nation's life is directly proportional to the image of teachers in the society.

\section{Priority of Directive Policy in Utilizing the Environment as a Source of Geography Learning}

The existence of various barriers in utilizing the environment as a learning source makes the directive policy to be a priority. Writer chose ISM because it can reveals direct and indirect relationship between variables based on the situation revealed where it is more accurate than the individual factors taken separately (Cagno et al., 2014). Attri et al., (2013) suggested that ISM technique is an interactive learning process in which different and directly related elements are structured into a comprehensive system model. So the ISM is very appropriate in determining the direction of policy. Determining the direction of policy is conducted by following stages of research in the form of tracking information sources and conducting expert surveys to review and define elements and sub elements, then setting it as follows: (1) Planning : improvement of school infrastructure facilities, geography structured planning by teacher to use the environment as a learning source, increasing learning budget, forming a committee to explore, analyze conditions and availability in the development of learning resources, and schools promote joint development projects/deliberations of learning resources and (2) Implementation : development of geography teacher skills in collaboration with other offices and schools, developing students' skills to find literature of learning source, giving an understanding to parties involved about the importance of using learning resources.

Sub elements of development in utilizing environment as a learning source in geography study include: (1) improvement of school infrastructure facilities, (2) development of geography teacher skills in 
collaboration with other offices and schools, (3) geography structured planning by teacher to use the environment as a learning source, (4) increasing learning budget, (5) developing students' skills to find literature of learning source, (6) giving an understanding to parties involved about the importance of using learning resources, (7) forming a committee to explore, analyze conditions and availability in the development of learning resources, and (8) schools promote joint development projects/deliberations of learning resources

Based on study results from five experts, it is determined eight sub elements that have strong interaction to analyze barriers in utilizing the environment as a source of geography learning. In line with (Mathiyazhagan and Haq, 2013) ISM is a better approach to resolve the complexity of relationships with many elements. Furthermore, these sub elements are then analyzed its level of interaction by ISM technique. The first stage is to study the contextual relationship in the form of SSIM-VAXO Matrix as in Figure 1.

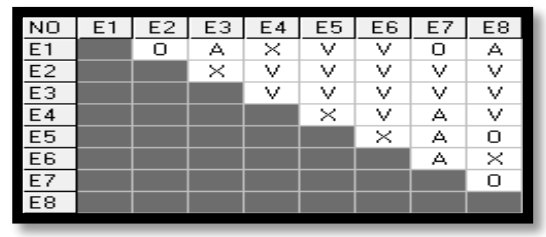

Figure 1. SSIM-VAXO Matrix of Learning Resource's Development Elements

The second stage is to transform the SSIM-VAXO matrix into a Reach ability Matrix (RM) binary number, then proceed to the third stage of transitive testing toward consistency in RM to obtain the final RM Matrix as shown in Table 1.

Table 1. Results of the Final Reach Ability Matrix of Development Elements

\begin{tabular}{|l|c|c|c|c|c|c|c|c|c|c|}
\hline NO & E1 & E2 & E3 & E4 & E5 & E6 & E7 & E8 & DP & F \\
\hline E1 & 1 & 0 & 0 & 1 & 1 & 1 & 0 & 1 & 5 & 3 \\
\hline E2 & 1 & 1 & 1 & 1 & 1 & 1 & 1 & 1 & 8 & 1 \\
\hline E3 & 1 & 1 & 1 & 1 & 1 & 1 & 1 & 1 & 8 & 1 \\
\hline E4 & 1 & 0 & 0 & 1 & 1 & 1 & 0 & 1 & 5 & 3 \\
\hline E5 & 1 & 0 & 0 & 1 & 1 & 1 & 0 & 1 & 5 & 3 \\
\hline E6 & 1 & 0 & 0 & 1 & 1 & 1 & 0 & 1 & 5 & 3 \\
\hline E7 & 1 & 0 & 0 & 1 & 1 & 1 & 1 & 1 & 6 & 2 \\
\hline E8 & 1 & 0 & 0 & 1 & 1 & 1 & 0 & 1 & 5 & 3 \\
\hline D & 8 & 2 & 2 & 8 & 8 & 8 & 3 & 8 & & \\
\hline L & 1 & 3 & 3 & 1 & 1 & 1 & 2 & 1 & & \\
\hline
\end{tabular}

Source: Primary data processing 2017

In Table 1, it can be seen that Sub-element 2, 3, 7 are in rank 1 and 2 with the largest value of Driver Power (DP) and the smallest dependency level (Dependence - D). The fourth stage is mapping of RM results in Table 1 into Sub-element classification based on Driver Power (DP) and Dependence (D) as in depicted Figure 2.

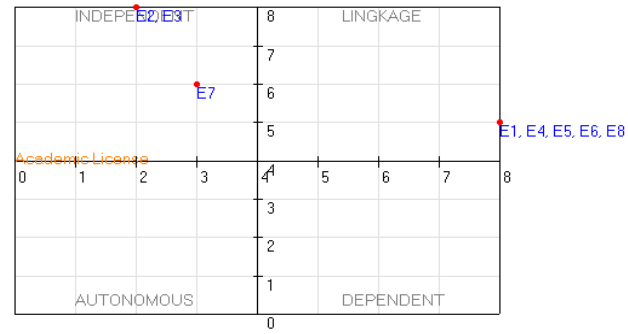

Figure 2. Classification Diagram of Learning Resource’s Sub-Element Development 
The classification of sub-elements is classified into quadrants:

Quadrant 1: Weak driver-weak dependent variables (Autonomous). The relationship of variables in this sector to the system is relatively small or unrelated.

Quadrant 2: Weak driver-strongly dependent variables (Dependent). The variables in this sector depend on inputs and actions given to the system, especially from the linkage variables.

Quadrant 3: Strong driver-strongly dependent variables (Linkage). The relationship between variables in this sector is unstable. Any action on that variable will have an impact on other variables.

Quadrant 4: Strong driver-weak dependent variables (Independent). The variables in this sector are called free variables whose elements/sub elements can be considered as key factors of the system.

From the above diagram can be known key factors that can be applied that was in quadrant 4 as follows:

1. Development of geography teacher skills in collaboration with other offices and schools

2. Geography structured planning by teacher to use the environment as a learning source

3. Forming a committee to explore, analyze conditions and availability in the development of learning resources The final stage is the preparation of sub-element hierarchy based on DP and D rank values. Study results put the overall sub elements in utilizing the environment as a source of geography learning as shown in Figure 3.

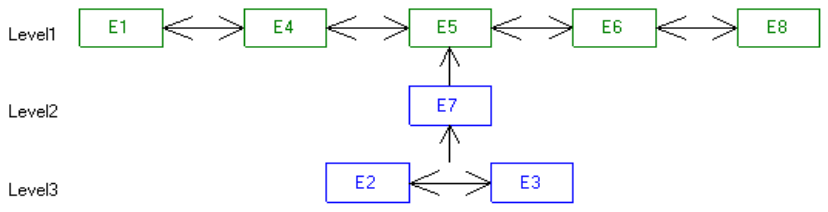

Figure 3. The Hierarchical Structure of Learning Resource's Sub-Elements Development

Based on the hierarchical structure there are three levels. The highest level will have the greatest influence and has the highest involvement to analyze the development in utilizing the environment as a source of geography learning.

\section{Conclusion}

Utilization of environment as a Learning Source to apply religious characteristic by geography teacher in SMAN East Lombok is as follows: The availability of physical and non physical environments in East Lombok can be utilized as a real learning resource by geography teachers to apply religious characteristics. Both physical and non-physical are available in existing environments within school and outside school. Both aspects are relevant to the Core Competencies and Basic Competencies for High School student. The environment has been utilized as a learning resource for applying religious characteristics by geography teachers, but to utilize the environment outside the school has not been optimal, because of the obstacles. In the obstacles aspect, some constraints that teacher encountered are the requirement of co-workers to coordinate students, infrastructure, planning, and to give understanding to parties involved such as parent, and also the need to analyze the availability in the development of learning resources. Interpretative Structural Modeling (ISM) method has been able to classify the entire sub elements into quadrants based on the value of Drive Power and Dependence and in the hierarchical structure based on Ranking and Level, which then it informs sub key elements that are: sub elements of Development of geography teacher skills in collaboration with other offices and schools, and structured planning by geography teacher to utilize the environment as a learning source and forming a committee to explore, analyze conditions and availability in the development of learning resources. 


\section{References}

Abdul Aziz, K. (2015). Application Reality of Knowledge Management Processes Practice in Leaning Resources Centres: Case Study of Learning Resources Centers in Makkah al-Mukarramah Schools in Saudi Arabia. ScienceDirect :ELSIVIELER

Ancok. and Suroso. (2001). Psikologi Islami. Yogyakarta : Pustaka Pelajar

Attri, R.Dev, N.,Sharma. (2013). Interpretive Structural Modeling (ISM) Approach : An Overview. Res. J. Manag.Sci. 2 (2), 3-8.

Cagno, E., Micheli,G.J.L., Jacinto,C., and Masi,D. (2014). An Interpretive Model of Occupational Safety Performance for Small-and Medium-Sized Enterprises. Int. J.Ind.Ergon. 44 (1), 60-74.

Hermon, D. (2014). Geografi Bencana Alam. Radjawali Press

Hermon, D. (2017). Climate Change Mitigation. Rajawali Pers (Radjagrafindo). Jakarta

Iswandi, and Indang, D. (2017). Pendekatan Sistem. Depok : Raja Grafindo Persada

Kemendiknas. (2010). Bahan Pelatihan : Penguatan Metodologi Pembelajaran Berdasarkan Nilai-Nilai Budaya untuk Membentuk Daya Saing dan Karakter Bangsa. Jakarta: Kemendiknas.

Majid,, A. (2012). Perencanaan Pembelajaran Mengembangkan Standar. Kompetensi Guru. Bandung: PT Remaja Rosdakarya

Mathiyazhagan, K., Haq, A.N. (2013). Analysis of the Influential Pressures for Green Supply Chain Management Adoption an Indian Perspective Using Interpretive Structural Modeling. Int. J.Adv. Manuf. Technol.,1-17

Permendikbud. (2016). Standar Proses Pendidikan Dasar dan Menengah. Jakarta: Kemendikbud.

Rohani, A. (1997). Media Instruktusional Edukatif. Jakarta : Rineka Cipta.

Sanjaya, W. (2008). Perencanaan dan Desain Sistem Pembelajaran. Jakarta : Kencana.

Sitepu. (2014). Pengembangan Sumber Belajar. Jakarta : Grafindo.

Sugandi, D. (2015). Pembelajaran Geografi sebagai Salah Satu Dasar Pembentukan Karakter Bangsa in SOSIOHUMANIKA: Jurnal Pendidikan Sains Sosial dan Kemanusiaan, Vol.8(2) November, pp.241252. Bandung, Indonesia: Minda Masagi Press and UNIPA Surabaya, ISSN 1979-0112.

Undang-Undang Republik Indonesia No.20 tahun 2003 tentang Sistem Pendidikan Nasional.

Usman, H. (2011). Manajemen. Teori, Praktik, dan Riset Pendidikan. Jakarta: Bumi. Aksara. 